\title{
THE DE MORTALITATE OF CYPRIAN: CONSOLATION AND CONTEXT ${ }^{1}$
}

BY

\section{J.H.D. SCOURFIELD}

The publication in 1937 of Charles Favez's monograph, La Consolation latine chrétienne,$^{2}$ opened up a new horizon in the study of ancient consolatory literature. Though this subject had been one of recurring interest to scholars during the previous hundred years, ${ }^{3}$ Favez was the first to pay serious attention to the Christian contribution to the genre, and to consider both its relation to and, in particular, its differences from, the consolatory writing of pagans such as Cicero, Seneca, and Plutarch. His approach was essentially synchronic. Themes, topics, expressions, materials found in those Christian texts which formed the basis of his study were brought together in such a way as to create a composite picture of Christian consolation, which could be compared as a whole with the pagan literature. That such an approach has limitations is clear. Favez also drew on a relatively narrow range of texts. As its title suggests, the book does not consider Christian consolatory writing in Greek, ${ }^{4}$ nor does it deal comprehensively with Latin work. ${ }^{5}$ But it remains a fundamental study, an essential starting-point for anyone working in the field.

The book is founded on the work of four authors: Jerome, ten of whose letters may broadly be classified as consolatory; ${ }^{6}$ Ambrose, from whom we have two letters of consolation, ${ }^{7}$ and funeral orations for his brother Satyrus and the emperors Valentinian II and Theodosius I; ${ }^{8}$ Paulinus of Nola, author of a letter to the Christian senator Pammachius on the death of his wife Paulina, and of a consolatory poem to Pneumatius, a relative by marriage; ${ }^{9}$ and Cyprian, whose De mortalitate, a sermon or tract addressed to the Christian community at Carthage, is presented by Favez as the earliest Christian consolation in Latin. The diversity of these texts is indicative of the difficulties we face in defining a consolatory genre; even the letters are highly individual in character, some of them containing little strictly consolatory or exhortatory ${ }^{10}$ material, ${ }^{11}$ or possessing other overriding aims. ${ }^{12} \mathrm{We}$ can 
perhaps do no better than to classify as consolatory those texts in which the consolation of the bereaved is one of the author's purposes. ${ }^{13}$ For the most part they draw on a relatively limited common stock of topics and arguments, a repertoire expanded and adapted by the Christians in accordance with Christian belief, but often displaying firm links with the pagan tradition.

Of the texts chosen by Favez as material for his study, the De mortalitate of Cyprian stands out from the rest in a variety of respects. It predates every other work under scrutiny by more than a century. ${ }^{14}$ It does not respond to the death of a particular individual, but to the troubles facing a whole community, including mass bereavement. It stands neither in the epistolographic tradition, nor in that of epideictic oratory. And as we shall see, the tone of the consolatory portions of the work is much more stark than is normal in the fourth- and fifth-century material.

Favez's inclusion of the De mortalitate in his book gave it a firm place in the history of ancient consolatory writing. ${ }^{15}$ But his treatment of it was later met with a number of criticisms. Thus Alfred Stuiber in 1955:

Mit der Schrift De mortalitate hat Cyprianus das antike Genus der Trostschrift in die christ.-lat. Literatur eingeführt (hierzu Ch. Favez ... der freilich die Unterschiedlichkeit zu andern, von den antiken Gattungstopoi stärkter geprägten christl. Consolationes nicht genügend ins Licht stellt ...). ${ }^{16}$

Another aspect of the difference between the De mortalitate and later patristic Latin consolation was stressed by Peter von Moos in 1971, in his huge work on the medieval consolatio. ${ }^{17}$ Associating the De mortalitate, by reason of its stern and rigorous attitude towards the expression of grief, with the letter of an unknown author to one Turasius on the death of his daughter, ${ }^{18}$ which he was inclined to date to the end of the third century, von Moos wrote of a climate of 'Christian Stoicism' lying behind Cyprian's sermon, and criticised Favez's view that one of the features which distinguished Christian from pagan consolation was the dominance in the former of feeling over reason: the early patristic evidence would not permit so general a conclusion. ${ }^{19}$ The judgements of both Stuiber and von Moos contain something of the truth. But, as I shall hope to show, the picture they present is in certain respects misleading and inaccurate. My aim in this paper is to take a fresh look at the De mortalitate and to consider how its consolatory character can 
best be explained. This will involve, inter alia, an examination of Cyprian's overall purpose in the work, and of the historical situation in which it belongs; it will necessarily involve a critique of the positions taken by Stuiber and von Moos. But first it will be appropriate to sketch the immediate background to the composition of the work, to indicate Cyprian's principal aims and approaches, and to gather together the consolatory elements of the treatise.

The De mortalitate was written in the midst of the great plague which broke out in the Roman world in the early $250 \mathrm{s.}{ }^{20}$ Though we cannot be certain, it seems probable that it represents the published text of a sermon originally delivered orally to the Christians of Carthage. Addressed to fratres dilectissimi, by which is probably meant the whole Christian community, ${ }^{21}$ the work responds to some of the consequences of the plague for and within that community. In particular, Cyprian is concerned to combat the undermining of religious convictions and appropriate Christian behaviour that the plague has caused. His avowed aim is set out in the single long sentence which forms the opening chapter of the treatise. While the faith of most of his audience is as solid as a rock in the face of the plague,

tamen quia animadverto in plebe quosdam vel inbecillitate animi vel fidei parvitate vel dulcedine saecularis vitae vel sexus mollitie vel, quod magis est, veritatis errore minus stare fortiter nec pectoris sui divinum adque invictum robur exerere, dissimulanda res non fuit nec tacenda, quominus quantum nostra mediocritas sufficit vigore pleno et sermone de dominica lectione concepto delicatae mentis ignavia conprimatur et qui homo Dei et Christi esse iam coepit Deo et Christo dignus habeatur. ${ }^{22}$

yet I observe that among the people there are some who, through weakness of spirit or insufficient faith, or because of the sweetness of the worldly life or the tenderness of their sex, or (what is worse) through making a mistake about the truth, stand less firm and do not display the divine and unconquered strength of their heart. Therefore this is not a matter for concealment or silence; I must speak, so that-as far as my limited powers are able-the lethargy of the feeble mind may be checked by full vigour and words drawn from holy Scripture, and those who have already begun to belong to God and Christ may be considered worthy of God and Christ. (c. 1) 
A matter of special concern was the fact that some Christians were troubled by the plague's inability to discriminate between them and the pagans, an anxiety which Cyprian attempts at some length to dispel in c. 8. Others presented a quite different problem: far from needing their faith strengthened, they feared that the plague might deprive them of the possibility of martyrdom. With this group Cyprian deals in c. 17, pointing out that martyrdom does not lie within their power, but is in the gift of God. Then again there were those who had suddenly and recently been bereaved in the pestilence. Their grief also had to be confronted.

In the early part of the treatise (cc. 2-6) Cyprian's attention is devoted to the attitude of his audience to their own deaths. For him the plague presages the end of the terrestrial world and the coming of the kingdom of heaven, which, for faithful Christians, should be a matter not for fear but for joy: death will take them to Christ, and they will be rid of the troubles and dangers which beset them in this world. Cyprian's first comment relating to bereavement grows out of this context. To support his case that death is something positive and advantageous, he quotes Jesus himself:

qui cum discipuli eius contristarentur, quod se iam diceret recessurum, locutus est ad eos dicens: 'si me dilexissetis, gauderetis quoniam vado ad Patrem', docens et ostendens, cum cari quos diligimus de saeculo exeunt, gaudendum potius quam dolendum.

When his disciples were saddened, because he said that he was now going to leave them, he said to them, 'If you loved me, you would rejoice that I am going to the Father'-teaching and showing us that when the dear ones whom we love depart from the world, we should rejoice rather than grieve. (c. 7)

The remainder of the chapter does not continue directly with the consolatory thread, though now that the theme has been introduced, what Cyprian proceeds to say can be seen to have relevance both to his audience and to the deceased (and is thus an implicit consolation to the bereaved): death (as he has said before) is a gain, an escape from the world, the flesh, and the devil, to the joy of eternal salvation.

After dealing with the problem of the plague's affecting pagan and Christian alike-he points out that as long as they are in the world, and have not yet put on incorruption and immortality, Christians will inevitably be subject to all the ills that flesh is heir to; indeed the Christian must labour more than other people, for he has to struggle with the 
assaults of the devil (cc. 8-9)-Cyprian urges his community to display patience and fortitude at this time of tribulation (cc. 10-14). In adversity the Christian is proved, like the potter's vessel in the furnace; the difference between Christians and pagans is that in such circumstances Christians do not complain but endure. The plague and all its revolting symptoms, which are graphically listed, serve to prove a Christian's faith. Clearly Cyprian's objective here is to put some backbone into his flock in the face of their troubles, and one of his techniques is to cite from Scripture instances of the kind of fortitude he is calling for. Here we can see at least a nod in the direction of the bereaved and their grief. The case of Job is particularly relevant to their situation, for one of Job's trials-and Cyprian is explicit about this-was the loss of his children (c. 10). Still more direct is the case of Abraham and Isaac, which illustrates not only, or even mainly, fortitude in tribulation, but obedience to the will of God, a theme which comes into greater prominence later in the work. To please God, Abraham was not afraid to lose his son, or to commit murder;

qui filium non potes lege et sorte mortalitatis amittere, quid faceres, si filium iubereris occidere? ad omnia te paratum facere timor Dei et fides debet.

If you cannot let go of a son by the law and lot of mortality, what would you do if you were ordered to kill your son? The fear of God and faith should make you prepared for anything. (c. 12)

The loss of one's property, the physical effects of disease, separation by death from one's wife, children, and other loved ones, should not be stumbling-blocks (scandala) but occasions for battle,

nec debilitent aut frangant christiani fidem, sed potius ostendant in conluctatione virtutem, cum contemnenda sit omnis iniuria malorum praesentium fiducia futurorum bonorum.

nor should they weaken or break a Christian's faith, but rather show his courage in the struggle, since all the harm caused by our present evils is to be despised by reason of our confidence in future joys. (c. 12)

To this final contrast I shall return.

Some of what follows can also be regarded as having a consolatory quality, though again the focus is less on the grief of the bereaved than on the anxieties of the audience about their own situation, the constant threat of a sudden and unpleasant death. When Cyprian says 
multi ex nostris in hac mortalitate moriuntur, hoc est multi ex nostris de saeculo liberantur

many of our people are dying in this plague, that is, many of our people are being liberated from the world (c. 15),

it is a kind of encouragement to the living both on their own account and on that of their departed loved ones. ${ }^{23}$ But it is not until c. 20 that Cyprian seriously confronts the question of the grief that is felt by those whose relatives and friends have died. The line he takes is perfectly consistent with his approach hitherto:

nobis quoque ipsis minimis et extremis quotiens revelatum est, quam frequenter adque manifeste de Dei dignatione praeceptum est, ut contestarer adsidue, ut publice praedicarem fratres nostros non esse lugendos accersitione dominica de saeculo liberatos, cum sciamus non amitti sed praemitti, recedentes praecedere, ut proficiscentes, ut navigantes solent, desiderari eos debere, non plangi nec accipiendas esse hic atras vestes, quando illi ibi indumenta alba iam sumpserint, occasionem dandam non esse gentilibus, ut nos merito ac iure reprehendant, quod quos vivere aput Deum dicimus ut extinctos et perditos lugeamus et fidem quam sermone et voce depromimus cordis et pectoris testimonio non probemus.

How many times has it been revealed also to me, the least and last of men, how frequently and plainly has the instruction been given by almighty God, that I should give continual witness and proclaim to all that our brothers should not be mourned, when they have been liberated from the world at the Lord's summons, since we know that they have not been sent away but sent ahead, that as they depart they are leading the way; they should not be lamented but missed as people who are setting out on a journey or voyage are generally missed, nor should we put on black garb here when they have already taken up white clothing there, and the opportunity should not be given to the heathen to rebuke us justly and deservedly, because we say that they are living with God, yet mourn them as if they were dead and lost for ever, and fail to prove by the testimony of our heart and mind the faith which we express in words. (c. 20)

The words of the apostle Paul at 1 Thess. 4: 13-14 are used to support this case. Those who have no hope are grieved at the deaths of their dear ones;

qui autem spe vivimus et in Deum credimus et Christum passum esse pro nobis et resurrexisse confidimus ... quid aut ipsi recedere istinc de saeculo nolumus aut nostros recedentes quasi perditos plangimus ac dolemus?

but we who live in hope and believe in God and trust that Christ suffered for us and was resurrected ... why are we ourselves unwilling to leave the world, and why do we mourn and grieve the departures of our loved ones as though they are lost? (c. 21) 
At this point Cyprian explicitly unites the two aspects of the situationthe fears of the surviving Christians and their attitude to the deceasedand this double perspective is retained throughout the remainder of this part of the work, the focus shifting from one aspect to the other, and sometimes settling on both; the famous words in the book of Wisdom, for example, 'raptus est ne malitia mutaret intellectum illius', ${ }^{24}$ frequently used in a consolatory way in later consolationes, ${ }^{25}$ are presented here in a context and a manner which allow them to be applied both to those who have already died and to those who still face the risk of an early death (c. 23). Finally, Cyprian calls on his listeners to be firm, courageous, and obedient to God's will, and to set their sights on eternal life:

potius, fratres dilectissimi, mente integra, fide firma, virtute robusta parati ad omnem voluntatem Dei simus, pavore mortis excluso immortalitatem quae sequitur cogitemus. hoc nos ostendamus esse quod credimus, ut nec carorum lugeamus excessum et cum accersitionis propriae dies venerit incunctanter et libenter ad Dominum ipso vocante veniamus.

Rather, beloved brothers, let us with pure hearts, unbending faith, and stout courage be prepared for every wish of God; shutting out the fear of death, let us contemplate the immortality which follows it. Let us show that this is what we believe, so that we do not mourn the departure of our dear ones, and that when the day of our own summons arrives, we come to the Lord at his call gladly and without hesitation. (c. 24)

The last two chapters (25-26) are a kind of summation of the arguments used by Cyprian to strengthen the faith and courage of his audience: the world is in collapse, and we should be grateful if we are extracted from it before our time; while on the other side, heaven, our true home, waits for us. There is some consolation for the bereaved in the notion (c. 26) that a great number of their loved ones are awaiting their arrival; but attention here is concentrated very much on the personal future of the living, not on their grief.

This summary should be sufficient to indicate that, as far as consolation is concerned, Cyprian's approach in the De mortalitate is to speak to the head, not to the heart. He utters no expression of sympathy, and is uncompromising in his rejection of grief as inappropriate for Christians. His position is that if the basic Christian premises are accepted, there is no room for grief. Christians should be glad if their loved ones have died, escaped the miseries of life on earth, and entered heaven; to grieve is to deny the faith. Only a single concession is granted to the 
bereaved: that those who have died may be missed (desiderari), 'ut proficiscentes, ut navigantes solent' (c. 20).

This approach is strikingly different from that found in most consolatory writing, whether pagan or Christian. If classic Stoic teaching, with its emphasis on reason, maintained that grief was irrational and to be suppressed, it had little impact on consolation in practice. The predominant view in the extant pagan texts is that while grief should not be indulged in, and a limit should be set to it, a certain amount of grief is permissible, even desirable. Cicero, for example, writing to Brutus after Porcia's suicide, says that to grieve at such a loss is necessary, for insensibility may be still more distressing; ${ }^{26}$ and even Seneca, with his mainly Stoic views, grants that there is a place for tears in moderation. ${ }^{27}$ Equally, the expression of sympathy was so accepted an ingredient of consolation that it found a place in rhetorical precept on consolatory writing..$^{28}$ Most Christian consolation is very much in this mould.$^{29}$ It is true that a tension can sometimes be observed between the feelings of grief that Christians experience and their recognition that the person mourned is in heaven and so ought not to be mourned ${ }^{30}$ (in terms of the logic of belief, there was more reason for pagans-whose belief in the afterlife tended to be at best shadowy and uncertain-to mourn their dead than for Christians), but the dilemma was capable of solution: the grief could be held (quite sensibly and realistically) to be not for the condition of the deceased, but for that of the bereaved themselves, separated from their loved one by his or her death. ${ }^{31}$ The Bible-centred culture of early Christianity also gave Christians an advantage over pagans in dealing with grief, in that amid the arguments furnished by Scripture for rejecting grief could be found precedents for admitting it. While precedents from the Old Testament could be problematic (early Christian eschatology maintained that until the opening of heaven to believing souls at Christ's resurrection, the souls of the dead remained

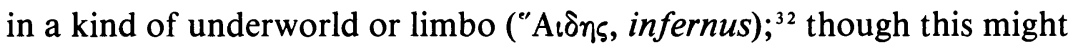
admit of degrees of comfort and discomfort, foreshadowing the joys of heaven and the torments of hell, heaven itself was out of reach; ${ }^{33}$ thus it could be argued that in those days grief at a person's death was appropriate, whereas following Christ's resurrection, when the prospect for the faithful was no longer infernus but heaven, it was not ${ }^{34}$ ), New Testament material was available which contained no such difficulties. Best of all was the case of Jesus himself weeping for Lazarus, before raising him back to life. ${ }^{35}$ Ambrose, Augustine, Paulinus of Nola, and 
Jerome all cite this incident to legitimise a certain amount of grief; ${ }^{36}$ indeed, Jerome even uses it to justify his own grief in his letter to Paula on the death of her daughter Blesilla, in which he is strongly critical of Paula's excessive mourning and offers her rebuke no less than consolation. ${ }^{37}$ Such material Cyprian ignores, though his approach throughout the De mortalitate is to base his arguments firmly on Scripture, which he frequently cites directly. That is to say, it would have been easy for Cyprian, and totally in accord with his attitude towards Scripture, to have given some comfort by way of allowing room for the expression of grief, if he had wanted to. Why Cyprian chose to proceed in a quite different way has now to be considered.

\section{III}

I begin with the idea mentioned earlier ${ }^{38}$ that the consolatory character of the De mortalitate can be explained in terms of a supposed climate of 'Christian Stoicism' which lay behind it. This expression has frequently been used in connection with this text ${ }^{39}$ without, however, being properly examined. As a broad descriptive term, evoking in modern readers notions of fortitude, self-control, and indifference to pain or pleasure, it may be held to characterise the tone of the work with some success. As an analytic term, it is patently unsatisfactory, indeed dangerously misleading. Marcia L. Colish has indicated, I believe rightly, that, for all the attempts to demonstrate the contrary, there is little genuine Stoic material in Cyprian..$^{40}$ The De mortalitate is one of the few texts where Colish detects such material: in it 'Cyprian adverts to two Stoic ethical principles ... the tranquillity resulting from the conceptualization of passing woes such as plagues as adiaphora and the magnitudo animi that enables the wise man to confront and to overcome tests of virtue of this type'; but, as she proceeds to observe, these notions have been fully assimilated to a Christian argument. ${ }^{41}$ Cyprian could draw on Stoicism to bolster or embroider a case, but he was no Stoic. Let us, however, ignore for a moment the inaccuracy of the expression, and consider the notion of a climate of thought believed to have influenced Cyprian in this work-a climate promoting a cold, cerebral attitude to Christian bereavement and grief. The idea is not exclusive to von Moos. J. Fontaine, ${ }^{42}$ criticising the view of $\mathrm{H}$. Koch that Cyprian displays a considerable direct debt to Seneca, ${ }^{43}$ saw at the back of Cyprian's work in general 'un climat stoïcien de la pensée chré- 
tienne, commun aux écrivains des Ilème et IIIème siècle $\langle\mathrm{s}\rangle$ '. Even though Cyprian's work shows few traces of Stoicism proper, might not his thought have been influenced by a prevailing atmosphere of a Stoical character within Christianity? Perhaps. But the notion of a climate of thought is a vague one, its existence not always easy to prove, and its range of operation impossible to establish precisely; ${ }^{44}$ and it is all too easy to have recourse to the idea in seeking an explanation for the consolatory character of the De mortalitate and the letter to Turasius with which von Moos associates it. ${ }^{45}$ Before doing so, we should see if good internal and situation-specific reasons for the approach to consolation adopted in these texts can be found.

In the case of the letter to Turasius, this is difficult. We know too little about the circumstances of its composition to make informed hypotheses about the reasons for its author's extraordinary severity towards his bereaved correspondent. Preserved in the corpora of both Cyprian and Jerome, ${ }^{46}$ but patently the work of neither of them, this letter is unparalleled in the depth of its feeling that grief is inappropriate for Christians; indeed, no ancient letter of consolation, pagan or Christian, shows such a lack of human sensibility as is found here. The opening lines state the author's fundamental message with shattering directness:

caritatis tuae scripta percepi, quibus animum tuum dolore commotum de filiae dormitione cognovi. non aliud principaliter admiratus sum quam christiani pectoris in te iactatam fuisse virtutem ut animum flexeris ad dolorem. stupeo murum fidei penetratum vulneribus orbitatis, quem saepire debuerat spes resurrectionis et regni caelestis. numquam spes cum dolore concordat nec fides aliquando sentit quamcumque iacturam.

I have received your letter, my dear Turasius, in which I learned that your daughter's passing has afflicted your mind with grief. What astonished me most of all was that the courage of your Christian heart had been shaken so much that you should turn your mind to sorrow. I am shocked that the wall of faith has been breached by the wounds of your bereavement, when the hope of resurrection and of the kingdom of heaven should have protected it. Hope and grief never go together, nor does faith ever feel any loss. (274.21-275.3)

The arguments set out in the following pages include a breathtakingly tendentious interpretation of the incident of Jesus weeping for Lazarus; far from using this to justify a measure of grief, the author claims that Jesus wept because he had to recall Lazarus to the life of this world: ${ }^{47}$ 
doluit Lazarum non dormientem, sed potius resurgentem, et flebat quem cogebatur propter salvandos alios saeculo revocare.

he mourned Lazarus not because he had fallen asleep but rather because he was coming back to life, and wept for the man whom he was obliged to summon back to the world for the sake of saving others. (276.9-12)

It is hardly too much to see in this letter the hand of a fanatic, whose intense commitment to basic Christian doctrine on death and resurrection left no room for emotion; a belief based on faith is maintained with a rigid rationality to the point of absurdity.

Several attempts have been made to establish the date and authorship of the letter to Turasius. The most detailed study of the piece, that of J. Duhr, ${ }^{48}$ attributes it to the Spanish monk Bachiarius, writing around the year 385. G. de Plinval saw Pelagian influence behind it, and conjectured that the author might be Pelagius' pupil Caelestius. ${ }^{49}$ In the view of G.W. Clarke all four pseudo-Cyprianic letters are Donatist forgeries. ${ }^{50}$ Von Moos associated the content of the letter with anteNicene apologetic, and suggested a late third-century date, in the period following the edict of toleration of Gallienus; ${ }^{51}$ he also accepted the arguments of $\mathrm{B}$. Melin ${ }^{52}$ that the letter was written by the same person as the De singularitate clericorum, another work falsely attributed to Cyprian. A thorough examination of the De singularitate led $\mathrm{P}$. Schepens ${ }^{53}$ to the conclusion that this text was composed in the middle of the third century; Schepens argued further, though tentatively, that the author may have been Lucius, bishop of Rome 253-4. If this date for the De singularitate, and Melin's identification of its author with the author of the letter to Turasius, could be accepted, we would have the intriguing possibility that a climate of thought specific to the 250 s was responsible for the consolatory character of the Turasius letter and the De mortalitate. But Melin's case for the identity of authorship, based on similarities of language, style, and rhythm in the two works, is not iron-clad; and other dates have been proposed for the De singularitate. ${ }^{54}$ In any event, proof that the letter to Turasius was composed around the same time as the De mortalitate would do no more than strengthen the suggestion that Cyprian's approach to consolation in his sermon was derived from a prevailing atmosphere rather than from reasons specific to the circumstances of composition and to Cyprian's other purposes in the work.

We should remind ourselves at this point that Cyprian's primary aim in the De mortalitate is not to offer consolation but to strengthen the 
Christian community of Carthage, buckling under the weight of the troubles brought by the plague. The perhaps natural propensity to lose faith in a benevolent God when catastrophe strikes will have been intensified by pagan allegations that it was Christian neglect of the traditional gods of Rome that was responsible for the disaster of the plague; it is this claim that Cyprian has to combat in the Ad Demetrianum. ${ }^{55}$ The Christians had in any case been embattled before the plague's arrival. It followed close on the heels of the first really thorough persecution, that instituted by the Emperor Decius late in 249 or early in 250. ${ }^{56}$ Decius' edict, which required all Roman citizens, or perhaps all inhabitants of the Empire, ${ }^{57}$ to sacrifice to the gods, may not have been a direct attack on Christianity; ${ }^{58}$ but it was the Christians whom the edict threatened most of all. Fabianus, bishop of Rome, met a martyr's death in January $250 ; ;^{59}$ and many Christians, in fear for their lives, lapsed, either complying with the demand or purchasing certificates which attested that they had done so when in fact they had not. ${ }^{60}$ The persecution had already waned when Decius died in June 251, and there is no firm evidence for a renewed persecution under his successor, Trebonianus Gallus; ${ }^{61}$ yet the atmosphere of the De mortalitate and the Ad Demetrianum is one of expectation that persecution might recur at any moment. ${ }^{62}$ That the fabric of Christian society at Carthage was under threat can occasion no surprise.

The attempt to understand the De mortalitate in the light of its historical context must also consider the position of Cyprian himself at this time. The date of composition of the work cannot be established precisely. The plague, set by ancient authorities in the reigns of Gallus and Volusianus (June 251-May 253), ${ }^{63}$ appears to have reached Rome by the late summer or autumn of $251 ;{ }^{64}$ it is generally accepted that it will have struck Carthage not later than the summer of 252, and the De mortalitate is commonly placed in that year. ${ }^{65}$ There is, however, some reason to think that it may belong not to 252 but to $253 .{ }^{66}$ The sense of coming persecution and the associated mood of foreboding about the end of the world, ${ }^{67}$ apparent also in the Ad Demetrianum, ${ }^{68}$ link the work with Cyprian's Letters 57 and 58, which are best (though not certainly) dated to that year. ${ }^{69}$ For the purposes of my argument it is not necessary to defend the choice of one year over the other; we are required only to recognise the possibility that the De mortalitate was written as late as the middle of 253 .

The preceding years had presented Cyprian with continual dif- 
ficulties. His election to the episcopate in 248 or $249,{ }^{70}$ only a few years after his conversion, had not met with universal approval at Carthage. It was opposed by a group of presbyters, ${ }^{71}$ perhaps prompted by resentment that a Christian of such short standing should gain the episcopal seat. Their hostility did not wane after the election was done. Nor did Cyprian do himself any favours in the Decian persecution by fleeing Carthage and going into hiding. The justifications offered by Cyprian and by his biographer Pontius for this action bear all the marks of rationalisation. ${ }^{72}$ His motives were brought into question, his flight criticised by the clergy of Rome. ${ }^{73}$ When he returned to Carthage after Easter $251,{ }^{74}$ following an absence of more than a year, ${ }^{75}$ it was to face a monumental problem of Church discipline: what was to be done about the vast numbers of Christians who had lapsed in the persecution? The question was intimately bound up with ecclesiastical power-politics. During his absence from the city Cyprian had initially taken a rigorous line on reconciling the lapsed with the Church, holding that no action should be taken until peace had been restored and it was possible to hold a Church council to consider the issue. This stand was exploited by his opponents among the clergy in Carthage, who attempted to undermine his position by readmitting the lapsed to communion without waiting for such a council and without insisting on due penitential procedure. ${ }^{76}$ In the summer of 250 Cyprian moved a short way towards a more relaxed policy, first allowing that those among the lapsed who had been granted certificates of forgiveness by martyrs should be reconciled if they were in danger of death, and then lifting the restriction of the provision to the holders of certificates. ${ }^{77}$ This stance matched that taken by the still bishopless clergy in Rome. ${ }^{78}$ But opposition persisted. Early in 251 the anti-Cyprian faction at Carthage found a new leader in the deacon Felicissimus. ${ }^{79}$ Readmission of the lapsed on easy terms gained a new impetus $;^{80}$ worse, Felicissimus threatened a complete split in the Carthaginian church. ${ }^{81}$ Though excommunicated by the ecclesiastical commission which Cyprian had recently appointed to administer the diocese in his absence, ${ }^{82}$ he was to remain a danger in the months which followed.

After his return to Carthage Cyprian set out, in the De lapsis and the De ecclesiae catholicae unitate, his position on the reconciliation of the lapsed and on episcopal authority. At a Church council which met during that summer Felicissimus was condemned, together with the five presbyters who had opposed Cyprian from the beginning. ${ }^{83}$ On the 
lapsed, the council came to a something of a compromise decision, though closer to the views of Cyprian than to those of the lapsists: those who had performed pagan sacrifices during the persecution (the sacrificati) were to be excluded from communion save at the point of death, while those who had purchased certificates attesting that they had sacrificed when in fact they had not (the libellatici) were to be readmitted to the Church following individual examination. ${ }^{84}$ This shift to a more lenient position can only have had the effect of weakening further the faction of Felicissimus.

The difficulties which Cyprian had faced, however, also involved relations with Rome. Over a year elapsed between the execution of Fabianus and the election of a new bishop. While in exile, Cyprian had had contacts with an influential Roman presbyter, Novatianus, who had shared Cyprian's rigorous views on the lapsed. ${ }^{85}$ Novatianus had good reason to expect that he would succeed to the episcopate. But perhaps because of his stance on the lapsed, his bid failed, the see passing into the hands of Cornelius (March 251) ${ }^{86}$ One of the five presbyters opposed to Cyprian at Carthage, Novatus, made capital out of this situation. Having gone to Rome to win support for his group (we may presume), he pressed Novatianus to organise his own election as counter-bishop to Cornelius. Though doctrinally at the opposite end of the spectrum from Novatianus on the matter of the lapsed, Novatus stood to gain at least some benefit from the association. Cornelius would have made a better ally, but he could not risk alienating Cyprian; the recruitment of Novatianus was a good second-best, for it would embarrass Cyprian and give the faction a powerful and educated supporter in Rome, whose prestige might be of benefit in the battle being waged within the Church in Carthage. Novatianus responded positively, and found three bishops to consecrate him. ${ }^{87}$

Cyprian allowed himself time for careful reflection before recognising Cornelius as legitimate bishop of Rome. ${ }^{88} \mathrm{He}$ undermined Novatianus' position by pressing a prestigious group of confessors at Rome to switch their allegiance to Cornelius, a step they proceeded to take ${ }^{89}$ His rival's power-base weakened, Cornelius was able to move strongly against him, and Novatianus was excommunicated. ${ }^{90}$

Novatus' failure with Novatianus, and the decision of the African council of 251, did not, however, see the end of opposition to Cyprian at Carthage. In 252 we find both lapsist and Novatianist anti-bishops in the city. The former, Fortunatus, had been one of Novatus' 
associates in the group of five presbyters; ${ }^{91}$ upon his consecration, Felicissimus led a delegation to Rome to inform Cornelius of the fact, no doubt looking for his support. ${ }^{92}$ Around the same time, Novatianus set up one of his followers, the presbyter Maximus, as a second rival bishop to Cyprian. ${ }^{93}$ The evidence does not suggest that Maximus' appointment was a serious threat to Cyprian; but the lapsists were plainly still a thorn in his flesh. Though in the event Felicissimus' mission to Cornelius was unsuccessful, Letter 59 makes clear that Cyprian was seriously disturbed by it. Thereafter Felicissimus vanishes from Cyprian's correspondence, but as it was-by the most likely reckoning ${ }^{94}$-only in 253 that an amnesty was issued by the Church at Carthage to all the penitent lapsed, the lapsist party must have continued to exercise attraction over a significant element of the Christian population there. Indeed, it is possible that Cyprian still faced opposition from them as late as $254 .^{95}$

It should be apparent from this brief summary of ecclesiastical politics in the first years of Cyprian's episcopate that there was never a time when Cyprian could rest assured that his position was secure. The arrival of the plague can only have increased his sense of instability. Though, in order to be consecrated at all, he must have had support among the clergy, it was to the massed laity that he owed his election as bishop. ${ }^{96}$ Apostasy and the plague will have eroded this power-base. When the plague struck, Cyprian's duty as a bishop required him to take the weakening Christian community by the scruff of the neck and somehow get it back into line. This was for the good of each individual soul, and of the church of Carthage as a whole. It was also for the good of Cyprian himself. His authority, constantly challenged in any case, relied on a church that was strong and unified, not one that was breaking up. It seems entirely reasonable to suppose that personal as well as pastoral considerations underlay Cyprian's purpose in the De mortalitate.

In attempting to strengthen and unite the Christian community Cyprian employs a variety of tactics. He seeks to inspire patience and fortitude by Scriptural example, and by presenting the plague as a test. $\mathrm{He}$ also tempts his audience into a firmer, more committed stance within the Church by turning their minds to the glories of heaven and contrasting this with the miseries of life on earth. A third tactic has perhaps been insufficiently appreciated. Early in the work, Cyprian declares that the Lord foretold the arising at different places of war, famine, earthquake, and pestilence (c. 2). He continues: 
magis ac magis in novissimis temporibus adversa crebrescere ante praemonuit. fiunt ecce quae dicta sunt, et quando fiunt quae ante praedicta sunt sequentur et quaecumque promissa sunt Domino ipso pollicente et dicente: "cum autem videritis haec omnia fieri, scitote quoniam in proximo est regnum Dei'. regnum Dei, fratres dilectissimi, esse coepit in proximo: praemium vitae et gaudium salutis aeternae et perpetua laetitia et possessio paradisi nuper amissa mundo transeunte iam veniunt: iam terrenis caelestia et magna parvis et caducis aeterna succedunt. quis hic anxietatis et sollicitudinis locus est? quis inter haec trepidus et maestus est nisi cui spes et fides deest? eius est enim mortem timere qui ad Christum nolit ire. eius est ad Christum nolle ire qui se non credat cum Christo incipere regnare.

The Lord forewarned that troubles would increase more and more in the last times. Look! What was stated is happening, and when the things which were predicted come to pass, what was promised shall also follow. The Lord himself made this promise: 'When you see all this happening, be sure that the kingdom of God is at hand.' The kingdom of God, dearest brothers, has begun to be at hand; the prize of life and the joy of eternal salvation and perpetual happiness and the possession of paradise that was but lately lost are now arriving as the world passes away; heavenly things are now succeeding earthly ones, small is yielding to great, the ephemeral to the eternal. What place is here for worry and anxiety? Amid all this, who is trembling and sorrowful except the person who lacks hope and faith? It is for him to fear death who is unwilling to go to Christ. It is for him to be unwilling to go to Christ who does not believe that he is beginning to reign with Christ. (c. 2)

Now we have no reason to suppose that Cyprian's apocalyptic views were not genuinely held. They appear elsewhere in his writings. ${ }^{97}$ But in the present situation they are also a convenient tactic. To emphasise that the end of the world is nigh can to some extent bring comfort: the miseries of life will soon be over, and those who trust in God can rest secure in the belief that they will indeed shortly see Christ and be reunited with their deceased relatives and friends. But it can also inspire fear. For those who may suspect that the lives they have lived have been less than adequate for a Christian, the imminent arrival of the end of the world will not have been an attractive prospect. In talking of such things-and in drawing attention to the very possibility of fear at the prospect (had he wished, he could have spoken only of the joy awaiting in heaven)-Cyprian is likely to have concentrated the mind wonderfully, and better than he could have done by reference to the plague alone. Death by pestilence may be avoided; there is no escaping the end of the world. Though Cyprian couches what he says here in indirect, third-person terms, there is no doubt that the backsliders will have recognised themselves. 
Later, the threat of eternal damnation is made more explicitly. The plague and all its ghastly symptoms serve as a test of Christian faith:

contra tot inpetus vastitatis et mortis inconcussis animi virtutibus congredi quanta pectoris magnitudo est, et quanta sublimitas inter ruinas humani generis stare rectum nec cum eis quibus spes in Deum nulla est iacere prostratum.

What stoutness of heart it is to contend against all those assaults of devastation and death with the qualities of one's soul unshaken, what exaltation to stand erect amid the ruins of the human race and not lie prostrate with those who have no hope in God. (c. 14)

Those who endure in this way have no reason to fear death; for others it is different:

mori plane timeat, sed qui ex aqua et spiritu non renatus gehennae ignibus mancipatur. mori timeat qui non Christi cruce et passione censetur. mori timeat qui ad secundam mortem de hac morte transibit. mori timeat quem de saeculo recedentem perennibus poenis aeterna flamma torquebit. mori timeat cui hoc mora longiore confertur, ut cruciatus eius et gemitus interim differatur.

Death indeed is to be feared, but by the man who, not having been born again from water and the spirit, is delivered up to the fires of hell. Let him fear to die who is not enrolled under the cross and suffering of Christ. Let him fear to die who from this death will pass to a second death. Let him fear to die whom, on his departure from the world, the eternal flame will torture in perpetual punishment. Let him fear to die to whom this is granted after a lengthy delay, so that his torments and groans may be postponed for a while. (c. 14)

This terrifying picture is soundly reinforced by the rhetorical repetition of the phrase mori timeat. Cyprian's message is plain: endure the plague, prove your faith, and you will gain your due reward, and have nothing to fear from death. But the torments of hell lie in wait for those who do not respond to what is required of them.

One of the techniques used by Cyprian to hold together the Christians of Carthage at this time is thus the arousal of fear for their immortal souls. That is to say, at the same time as he reminds them of the bliss that lies in store for the faithful, he disquiets them with the thought of its opposite. Part of his technique is to discomfort. In this a reason for the kind of consolation Cyprian offers in the work may be discernible. In as much as he seeks to disturb the backsliders in his community, it makes no sense for him to be lavish in consoling them. The Christian truth of eternal life for the faithful is firmly underlined. To go further, 
to express sympathy and permit grief, to 'hold', as we might say, the bereaved in their suffering, would in some sense be to undo the effect of the discomforting.

But with or without the terror tactics, the evocation of the end of the world and the fires of hell, Cyprian's rigorous attitude towards the expression of grief should occasion no surprise in its context. The general setting is of the greatest importance. Cyprian, as bishop, is addressing his community, the Gemeinde. The situation is one of peculiar difficulty. First persecution, now plague, and fears of further persecution lurking in the background. Speaking as bishop to people, and in such circumstances, Cyprian is called upon above all to deliver appropriate Christian teaching. The nature of the teaching demanded is perfectly clear. As we have seen, Cyprian warns his people of the torments of hell. He also tells them that the earth is a place of pain, trouble, and danger; a place of storms (c. 3), a place where every day Christians have to fight against the devil and his armoury (c. 4). Nor is it a Christian's real home. Life on earth is captivitas (c. 18); the true Christian patria is paradise (c. 26). But earthly life is of only temporary duration; the sufferings of the faithful will be brought to an end, to be succeeded by everlasting joy. The promises of God are very much in Cyprian's mind throughout. It seems to him absurd that people should fear death and cling to the world:

Deus de hoc mundo recedenti inmortalitatem adque aeternitatem pollicetur, et dubitas?

God promises you immortality and eternity when you leave this world, and you hesitate? (c. 6)

The point to bring out here is this. For Cyprian, God's promise of a blissful future renders earthly sufferings of no account. Let us recall a passage cited earlier:

contemnenda sit omnis iniuria malorum praesentium fiducia futurorum bonorum.

all the harm caused by our present evils is to be despised by reason of our confidence in future joys. (c. 12)

Our attempt to understand Cyprian's approach to consolation in this work requires us to take this statement seriously. It is related by him specifically to the loss of loved ones in the plague. If we give it weight, the implication is clear. From the perspective of the bishop instructing 
his flock, loss, and the grief resulting from it, are of minimal significance; sympathy and consolation are thus not called for. Though Cyprian does not cite it in this work, the underlying thought may owe something to Romans 8, where Paul writes that our sufferings are slight in comparison with our future glory (8: 18 'non sunt condignae passiones huius temporis ad futuram gloriam quae revelabitur in nobis'), and that nothing can separate us from the love of Christ, including (we should observe) persecutio and periculum (8: 35). It is perhaps significant that the first of these passages is cited by Cyprian in the $\mathrm{Ad}$ Quirinum, a compilation of Biblical testimonia under various heads put together probably before $250,{ }^{98}$ under the heading 'minora esse quae in saeculo patimur quam sit praemium quod promissum est' ('the things we suffer in the world are of less account than the promised reward'; Quir. 3.17). ${ }^{99}$

Another section of the Ad Quirinum, to which attention was drawn in connection with the De mortalitate by Stuiber, ${ }^{100}$ is still more significant. In this section Cyprian collects Scriptural texts under the heading 'neminem contristari morte debere, cum sit in vivendo labor et periculum, in moriendo pax et resurgendi securitas' ('no one should be made sorrowful by death, for in life there is toil and danger, but in death peace and the certainty of resurrection'; Quir. 3.58). Eight of the thirteen texts there collected recur, in quotation or by allusion, in the De mortalitate. Cyprian's attitude in our treatise is thus quite consistent with that expressed in the earlier, non-consolatory work. A very similar position was taken half a century earlier by Tertullian in the De patientia. In this tract Tertullian strongly criticises grief at the death of loved ones. Paul, he says, forbids us to be grieved when someone dies, like the pagans who have no hope;

et merito: credentes enim < in > resurrectionem Christi in nostram quoque credimus propter quos ille et obiit et resurrexit. ergo cum constet de resurrectione mortuorum, vacat dolor mortis ... cur enim doleas si periisse non credis? cur inpatienter feras subductum interim quem credis reversurum? profectio est quam putas mortem. non est lugendus qui antecedit sed plane desiderandus. id quoque desiderium patientia temperandum: cur enim inmoderate feras abisse quem mox subsequeris?

and rightly: for believing in Christ's resurrection we also believe in our own, for it was for us that he died and rose again. And so since the resurrection of the dead is established, there is no room for grief at death ... For why grieve if you do not believe that a person has perished? Why should you be impatient that someone has been stolen away for a while when you 
believe that he will return? What you take to be death is merely a departure. He who goes before you is not to be mourned but simply missed. And that sense of missing is to be tempered with patience; for why should you take it excessively badly that a person has gone away when you will soon follow? (pat. 9.2-3).

The contrast between mourning (lugere) and longing (desiderare) is apparent also in c. 20 of the De mortalitate, and in tone our text closely resembles the Tertullian passage. The position adopted by Cyprian in both the Ad Quirinum and the De mortalitate, and by Tertullian in the De patientia, is in a sense theoretical. The doctrine is based firmly on the logic of Christian belief, without regard to the realities of human experience. In terms of this logic, Christians do not need to be consoled upon the death of loved ones who are also Christian; the De mortalitate, regarded in its consolatory aspect, thus takes on the character of an anticonsolatio. This is exactly what we should have expected of Cyprian, the bishop and leader of his community, instructing them at a time of special crisis.

\section{IV}

In this paper I have attempted to demonstrate that the consolatory character of Cyprian's De mortalitate is explicable in terms of the social setting of the work and its precise historical context, the situation of the Church in Carthage and the difficulties besetting Cyprian himself. I have argued that there is no need to see a particular climate of thought at the back of it, as von Moos and others have suggested. ${ }^{101}$ Nor is there any reason to suppose that early Christian consolation in Latin was fundamentally different in its attitude to grief from later consolation, as von Moos implies. The facts are that we have only two texts, ${ }^{102}$ one of which (the letter to Turasius) cannot be securely dated, while the rigour of the other, the De mortalitate, is (so I maintain) completely understandable in the situation to which it belongs, and would be no less so in the fourth century or any other period in which similar circumstances appeared. The point is that Cyprian is not writing a letter of condolence to a bereaved friend, or delivering a speech before grieving relatives at a funeral, or speaking personally to a fellow-Christian who had lost a loved one. Cyprian was a human being as well as a bishop, and there are no good grounds for believing that he would have followed in circumstances of this kind the approach he adopts for very special reasons 
in the De mortalitate. This text is not evidence that an absence of sympathy and an insistence on reason would have informed his utterances in ordinary circumstances of bereavement.

The assertions of von Moos about the character of the De mortalitate and the importance of this for our understanding of Christian Latin consolation thus call for careful qualification. Similarly, the observations of Stuiber ${ }^{103}$ need to be modified and elaborated. First, the claim that Cyprian introduced into Christian Latin literature 'the ancient genre of the Trostschrift' is misleading. As I have pointed out above, ${ }^{104}$ a consolatory genre can at best be loosely defined, and while the consolatory portions of Cyprian's work have connections with earlier (pagan) consolatory writing, these amount to no more than a few mostly commonplace topics and expressions; ${ }^{105}$ consolation is only a subsidiary aim, and Cyprian owes nothing to past consolers in the matter of form. Thus while the De mortalitate offers the first example in Christian Latin literature of consolation in practice, we should not overestimate the significance of this. More importantly, Stuiber's stress on the difference between the De mortalitate and other Christian consolationes 'more strongly moulded by the ancient topics of the genre' gives a distorted picture, for it takes no account of context. The consolation which Cyprian offers in the work is (to reiterate) shaped by the setting and his other, more critical concerns; his comfort is the cool, cerebral comfort of Christian truth. Such a standpoint puts beyond use much of the traditional consolatory material employed by his pagan predecessors and his Christian successors alike.

NOTES

A primitive version of this paper was presented at the 18th Biennial Conference of the Classical Association of South Africa at Rhodes University in January 1989 (abstract in AClass 32 (1989), 133-4); a more evolved version at the University of Western Ontario in April 1991, thanks to the kind offices of Professor D.E. Gerber. I am grateful to Professor Gerber and his colleagues for providing a most congenial forum for me to try out my ideas, and for their comments. I also wish to thank Professor Albrecht Dihle and Dr Flora Manakidu for discussions which helped me to clarify my thoughts on this subject. The paper is dedicated to the memory of Eric Ashby (1904-92), Thomas James Davies (1917-93), and John Godfrey Griffith (1913-91), to all of whom I owe so much.

2 Paris, 1937.

3 The important general studies are those of A.C. van Heusde, Diatribe in locum philosophiae moralis qui est de consolatione apud Graecos (Utrecht, 1840), A. Gercke, 
'De consolationibus', Tirocinium philologum sodalium Regii Seminarii Bonnensis (Berlin, 1883), 28-70, C. Buresch, 'Consolationum a Graecis Romanisque scriptarum historia critica', Leipziger Studien zur classischen Philologie, 9 (1886), 1-170, and C. Martha, 'Les Consolations dans l'Antiquité', in his Études morales sur l'Antiquité (4th edn., Paris, 1905), 135-89.

4 There is no all-embracing study of the Greek material. The Cappadocian Fathers are well served by R.C. Gregg, Consolation Philosophy: Greek and Christian Paideia in Basil and the Two Gregories (Patristic Monograph Series, 3; Cambridge, Mass., 1975); other useful work inclu $\rightarrow$ J.F. Mitchell, 'Consolatory Letters in Basil and Gregory Nazianzen', Hermes, 96 (1968), 299-318, L. Malunowiczówna, 'Les Éléments stoïciens dans la consolation grecque chrétienne', in Studia Patristica, 13. Papers presented to the Sixth International Conference on Patristic Studies held in Oxford 1971, Part 2, ed. E.A. Livingstone (Texte und Untersuchungen, 116; Berlin, 1975), 35-45 (chiefly on John Chrysostom), $: \rightarrow$ M.M. Wagner, 'A Chapter in Byzantine Epistolography: The Letters of Theodoret of Cyrus', Dumbarton Oaks Papers, 4 (1948), 119-81, esp. 157-60.

5 The most serious omission is that of Augustine, for whose contribution see Favez, 'Les Epistulae 92, 259 et 263 de S. Augustin', $M H 1$ (1944), 65-8, and M.M. Beyenka, Consolation in Saint Augustine (Catholic University of America Patristic Studies, 83; Washington, DC, 1950), and 'Saint Augustine and the Consolatio Mortis', CBull 29 (1953), 25-8.

6 Jer. epist. 23, 39, 60, 66, 75, 77, 79, 108, 118, 127.

7 Ambr. epist. 15, 39.

8 Consolation could be a significant element in funeral oratory. Around AD 300

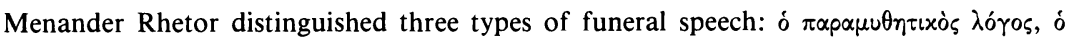

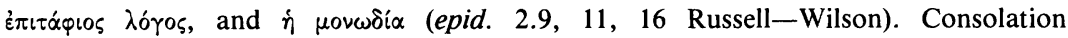
predominates in the first of these, and has a firm place too in the second; there is nothing directly consolatory in the third. Though surviving speeches cannot easily be straitjacketed into one or other of these categories, those of, for example, Gregory of Nazianzus on his father and his brother Caesarius (orat. 18 and 7 respectively), or Gregory of Nyssa on Theodosius I's wife Flacilla and daughter Pulcheria, have, like those of Ambrose, considerable consolatory content.

9 Paul. Nol. epist. 13, carm. 31.

10 Exhortation to bear the loss of a loved one in an appropriate way commonly accompanies consolation proper.

"For instance, Jer. epist. 108, the avowed purpose of which is to console the virgin Eustochium on the death of her mother, Jerome's close friend Paula (108.2.2), has negligible consolatory content; it is, rather, a eulogistic memoir of the deceased woman. The same is true of epist. 127, which celebrates the praises of the widow Marcella; indeed, a consolatory aim is here still less apparent.

12 In epist. 66 Jerome's principal concern is to praise his addressee, Pammachius, rather than to comfort him for the loss of his wife Paulina; while in epist. 118 he takes the opportunity afforded by the deaths of the wife and two daughters of his correspondent, Julian, to encourage him to adopt a new life of poverty. Likewise Augustine's main purpose in epist. 259 is to urge the recently widowed Cornelius to give up his life of sexual promiscuity.

13 We might also include texts containing material which might be used in practical consoling, such as the first and third books of the Tusculan Disputations of Cicero, or 
Ambrose's treatise De bono mortis. It should not be forgotten, either, that consolation could be offered on misfortunes other than bereavement, such as exile or illness.

14 It belongs to $\mathrm{AD} 252$ or 253 (see below, p. 23). The next of the group in chronological sequence are the two speeches of Ambrose on the death of Satyrus (AD 378).

is It is unmentioned in any of the works cited in n. 3 above. Its consolatory character was, however, recognised by modern scholars before Favez; see esp. M.L. Hannan, Thasci Caecili Cypriani De mortalitate: $A$ Commentary with an Introduction and Translation (Catholic University of America Patristic Studies, 36; Washington, DC, 1933), pp. v, 2-3, who properly drew attention to Pont. vita Cypr. 7.7. But Favez's book had the effect of establishing a canon of Christian Latin consolatory writing, with the De mortalitate first in chronological sequence; so, most recently, the diachronic study of G. Guttilla, 'La fase iniziale della consolatio latina cristiana', $A L C P$ 21-2 (1984-5), 108-215, begins with the Cyprianic text.

16 A. Stuiber, 'Cyprianus I', in Reallexikon für Antike und Christentum, ed. T. Klauser et al. (Stuttgart, 1950-), 3.463-6, at 465.

17 P. von Moos, Consolatio: Studien zur mittellateinischen Trostliteratur über den Tod und zum Problem der christlichen Trauer (Münstersche Mittelalter-Schriften, 3; 4 vols., Munich, 1971-2).

18 On this text see below, p. 22.

19 Von Moos (n. 17), 1.26-7 (C 23-4).

20 For the date of the plague see below, p. 23.

${ }^{21}$ In general Cyprian seems to prefer dilectissimi when addressing the laity, and carissimi when addressing the clergy, though his practice is far from rigid; see M.G.E. Conway, Thasci Caecili Cypriani De bono patientiae (Catholic University of America Patristic Studies, 92; Washington, DC, 1957), 95-6.

22 Quotations are drawn from the text of M. Simonetti (CCSL 3A).

${ }^{23}$ It is in the light of this passage, and the elaboration of it which follows, that we should read the somewhat surprising comment later in the same chapter that the fears engendered by the plague have had a positive effect in jolting lukewarm and lax Christians, apostates and unbelievers, into the front line of the Christian army. While some doubtless responded that way, the statement goes against the entire grain of mort. If, however, we see it as being written in the same encouraging tone as the earlier part of the chapter (the plague is a benefit not only because it frees Christians from the world, but because it brings new and restores lapsed Christians to the fold of the Church), we will not be misled into taking it too seriously. The idea that the Church has been strengthened by the addition of new Christians and old, who will fight, when battle comes, will have made some kind of appeal to each individual's need for support and solidarity; but Cyprian is dealing here more in rhetoric than in truth.

24 Wisd. 4: 11.

${ }^{25}$ Cf. Jer. epist. 39.3.1, 60.2.1, 75.2.1, 79.2.4, Paul. Nol. epist. 13.6, Ambr. exc. Sat. 1.30, Theodoret, epist. 136 (Collectio Sirmondiana; Sources chrétiennes, 111).

${ }_{26}$ Cic. ad Brut. 1.9.2; cf. ad Att. 12.10.

27 Sen. dial. 6.7.1, 11.18.6, epist. 63.1, 99.16.

28 Theon 2.117.16-24 Spengel, [Dion. Hal.] rhet. 6.4, p. 281.8-12 Usener-Rademacher. See too the sample letters of condolence in the treatises on epistolography by Demetrius and pseudo-Libanius (Demetr. form. epist. 5, [Liban.] char. epist. 21, 62 Weichert). 
29 For the permissibility of grief in moderation see e.g. (among many instances) Ambr. exc. Sat. 2.1, 2.11, Jer. epist. 39.5.2, Paul. Nol. epist. 13.10, Aug. epist. 263.3, Bas. epist. 62, Greg. Naz. epist. 165.2, orat. 7.1, John Chrys. epist. 197, Theodoret, epist. 14 (Collectio Sirmondiana; Sources chrétiennes, 98); for expression of sympathy, e.g. Ambr. epist. 15.1, Jer. epist. 60.1.1, 75.1.1, Bas. epist. 5.1, 29, 302 ad init., Greg. Naz. orat. 7.18, John Chrys. epist. 192, Theodoret, epist. 136 (Collectio Sirmondiana; Sources chrétiennes, 111). The element of lamentation often found in funeral orations may itself be seen as a legitimator of grief.

${ }^{30}$ The dilemma is expressed most sharply by Jerome at epist. 60.2.1-2; cf. Paul. Nol. carm. 31.7-10, Sulp. Sev. epist. 2.7.

${ }_{31}$ Cf. e.g. Jer. epist. 39.1.1, 60.7.1, 75.1.1, Ambr. epist. 39.5, obit. Valent. 46, Sulp. Sev. epist. 2.7-8, (for pagan parallels) Sen. dial. 6.12.1, [Plut.] ad Apoll. 19 (111E). The bereaved might also grieve their own lot at having been left amid the evils of life, while the deceased loved one enjoys the blessings of heaven; for this topic see e.g. Greg. Naz. orat. 7.20, Jer. epist. 60.7.2, 108.30.2.

32 This is the normal view from the fourth century at least. In the second and third centuries a different (though not certainly dominant) eschatology is apparent, according to which all departed souls, with a few special exceptions, remained in Hades until the General Resurrection; on this see A. Stuiber, Refrigerium interim: die Vorstellungen vom Zwischenzustand und die frühchristliche Grabeskunst (Theophaneia: Beiträge zur Religions- und Kirchengeschichte des Altertums, 11; Bonn, 1957), with the review of J.M.C. Toynbee, JThS 9 (1958), 141-9, and more recently C.E. Hill, Regnum caelorum: Patterns of Future Hope in Early Christianity (Oxford, 1992). But it is clear in mort. (and elsewhere in Cyprian; see Hill, 143-53) that Cyprian regards heaven as being already open to all faithful souls; see esp. cc. 5, 22, 24, 26, and also B. de Margerie, 'L'Interêt théologique du "De mortalitate” de saint Cyprien', Sciences ecclésiastiques, 15 (1963), 199-211. ${ }_{33}$ The whole position is made very clear in Jerome's homily on the story of the rich man and Lazarus (hom. in Luc. 16: 19-31; CCSL 78.507-16), at 509.78-510.96 (reading paradisi veritas <non> est at 95), 514.247-515.272.

${ }^{34}$ So Jer. epist. 39.4, 60.6 (on which see the explanatory comments of J.H.D. Scourfield, Consoling Heliodorus: A Commentary on Jerome, Letter 60 (Oxford, 1993), 122-4).

35 For the whole episode see John 11: 1-44; Jesus weeps at v. 35. It cannot be denied that Jesus was weeping for a man who, in terms of the belief outlined above, could not have been in heaven. But neither was Lazarus gone and lost to his loved ones for the rest of their time on earth; and in any case, Jesus' action will, here as elsewhere, commonly have been regarded as a model of right behaviour.

${ }^{36}$ Ambr. exc. Sat. 1.10, Aug. epist. 263.3, Paul. Nol. epist. 13.4, Jer. epist. 60.7.2.

37 Jer. epist. 39.2.1.

38 Above, p. 13.

${ }^{39}$ Without seeking it out, I have found it at P. Monceaux, Histoire littéraire de l'Afrique chrétienne depuis les origines jusqu'à l'invasion arabe, 2. S. Cyprien et son temps (Paris, 1902), 307 (which seems to be the fons et origo), Hannan (n. 15), 12, R.J. Deferrari, Saint Cyprian: Treatises (Fathers of the Church, 36; New York, 1958), 198 (who is plainly dependent on Hannan), V. Saxer, Vie liturgique et quotidienne à Carthage vers le milieu du IIIe siècle: le témoignage de saint Cyprien et de ses contemporains d'Afrique (Studi di antichità cristiana, 29; Vatican City, 1969), 267, M. Spanneut, Tertullien et les premiers moralistes africains (Paris, 1969), 95, as well as von Moos (n. 17), 1.27 (C 24). 
40 M.L. Colish, The Stoic Tradition from Antiquity to the Early Middle Ages (Studies in the History of Christian Thought, 34-5; 2 vols., Leiden, 1985), 2.33-5.

${ }_{41}$ Colish (n. 40), 2.34.

42 J. Fontaine, Aspects et problèmes de la prose d'art latine au IIIe siècle: la genèse des styles latins chrétiens (Lezioni Augusto Rostagni, 4; Turin, 1968), $158 \mathrm{n} .14$. He is followed by M. Naldini, 'Note esegetiche al “De lapsis” di s. Cipriano', GIF 9 (1978), 57-72, at $57 \mathrm{n} .1$.

${ }_{43} \mathrm{H}$. Koch, Cyprianische Untersuchungen (Arbeiten zur Kirchengeschichte, 4; Bonn, 1926), 286-313 ('Cyprian und Seneca'). The links made by Koch between Cyprian and Seneca 'ne sont pas tous absolument convaincants', wrote Fontaine (n. 42), with remarkable understatement. Less reserved is the judgement of Colish (n. 40), 2.34 with n. 85. Considering only mort., I can accept the influence of Sen. dial. 1.4.5 'gubernatorem in tempestate, in acie militem intellegas' on mort. 12 'gubernator in tempestate dinoscitur, in acie miles probatur', and perhaps of dial. 10.12.6 'delicati animi languore' on mort. 1 'delicatae mentis ignavia'; but that is all.

${ }^{44}$ Generalisation is always involved in this concept. We may speak of a climate of antiSemitism in Germany in the 1930s, or of sexual liberation in the West in the 1960s, or of free enterprise in Britain and the United States in the 1980s; this does not mean that everyone in those places at those times was anti-Semitic, sexually promiscuous, or committed to free-market economics, responding robotically to the prevailing trend. In the case of the Church in the second and third centuries, a rigorous, Stoical strain is evident; but this was not universal, and a Christian could take a more rigorous position on one matter and a less rigorous one on another-Cyprian, for example, was strict (though adaptive) on the question of reconciling the lapsed, but relaxed (though necessarily defensive) on the legitimacy of flight in time of persecution. And it would be foolish to suppose that the views of individuals were always constant, and did not bend at times to circumstance.

45 See above, p. 13.

46 Ps.-Cypr. epist. 4 (CSEL 3.3.274-82, from where the quotations below are drawn), ps.-Jer. epist. 40 (PL 30.278-82). See also PL 33.1175-6, where the opening of the letter appears among works falsely attributed to Augustine, the attribution in this case occurring in a single manuscript, it seems.

47 Duhr (below, n. 48), 555-7, cites as a parallel a passage from a homily attributed to Origen (but now ascribed with certainty to Gregory of Elvira), by which he claims the author of the Turasius letter was influenced at this point (for the text of this homily see A.C. Vega, S. Gregorii Eliberritani episcopi opera omnia primum collecta, 1 (Scriptores ecclesiastici hispano-latini veteris et medii aevi, 12-15; Escorial, 1944), 73-83 (tract. 7); the passage occurs at 79.4-7). But in fact a quite different explanation of Jesus' weeping is given there, and a direct debt is most improbable.

48 J. Duhr, 'Une lettre de condoléance de Bachiarius (?)', RHE 47 (1952), 530-85.

49 G. de Plinval, Pélage: ses écrits, sa vie et sa réforme (Lausanne, 1943), 254 n. 3.

so G.W. Clarke, 'The Epistles of Cyprian', in Auckland Classical Essays presented to E.M. Blaiklock, ed. B.F. Harris (Auckland, 1970), 203-21, at 214 n. 12.

st Von Moos (n. 17), 1.26-7 (C 23).

52 B. Melin, Studia in corpus Cyprianeum: commentatio academica (Uppsala, 1946), 211-32. 
53 P. Schepens, 'L'Épitre “De singularitate clericorum"' du pseudo-Cyprien', RecSR 12 (1922), 178-210, 297-327, and 13 (1923), 47-65.

54 They range as late as the eighth or ninth century; Dr Fell's suggested date of around AD 1000 postdates the earliest extant manuscript. Melin (n. 52), 213-15, however, makes clear that the work must be placed earlier than Caesarius of Arles (bishop from 502), who draws on it in a letter to an abbess and her congregation. For the conjectures of various scholars see Schepens (n. 53), 12.178-80, Koch (n. 43), 426-72 ('Zur pseudo-cyprianischen Schrift De singularitate clericorum'), at 426-8, 472, R. Gryson, Les origines du célibat ecclésiastique: du premier au septième siècle (Recherches et synthèses de sciences religieuses, section d'histoire, 2; Gembloux, 1970), 195 n. 6.

ss See esp. Dem. 2-3, 5, 23; the Christians were also held responsible for calamities other than that of the plague (war, famine, drought).

s6 For an excellent discussion of the Decian persecution see G.W. Clarke, The Letters of St. Cyprian of Carthage (Ancient Christian Writers, 43-4, 46-7; 4 vols., New York, 1984-9), 1.21-39. This is a major work of scholarship, an invaluable tool for the study not only of Cyprian's letters themselves but of the whole period covered by his episcopate. 57 For this view see Clarke (n. 56), 1.26-8. The Jews will have been excepted; see Clarke, 1.24 with $n .117$.

s8 Other evidence makes it clear that Decius was seeking to consolidate his claim to imperial power by appeal to tradition, and as it is most improbable that Christian numbers had as yet grown to such an extent that Christianity appeared a serious menace to the state, it seems sensible to locate the edict in this more general context: as demanding a religious rally expressing old-fashioned Roman values. This need not mean that Christian 'atheism' did not feature in the thinking behind the edict, but on this view it is only one aspect of the picture. For discussion see e.g. W.H.C. Frend, Martyrdom and Persecution in the Early Church: A Study of a Conflict from the Maccabees to Donatus (Oxford, 1965), 404-6, Clarke (n. 56), 1.22-5, R. Lane Fox, Pagans and Christians (London, 1986), 450-4.

s9 Cf. Euseb. hist. eccl. 6.39.1, (for the date) Liber pontificalis 21 (19 January), Martyrol. Hieron. (Acta sanctorum, Nov., 2.2, ed. H. Delehaye and H. Quentin (Brussels, 1931), 50) (20 January).

60 For the libellatici see esp. Cypr. laps. 27, epist. 55.13-14.

61 On the question of persecution under Gallus see Clarke (n. 56), 3.4-17.

62 Cf. mort. 15, 19, Dem. 12-13, 17, 21, 25. In Dem. particularly, Cyprian writes of persecution as if it is a present reality rather than a future expectation; but his comments are too unspecific to be convincing evidence that persecution was actually happening at the time of writing, and in my view they are best read as expressing a belief that a phase of persecution-which might not be continuously oppressive-was in progress. See further Clarke (n. 56), 3.7-8. It should also be recognised, however, that the Carthaginian Christians were in all probability harassed by pagans who blamed them for the plague and everything else (see above, n. 55), without this being associated with 'official' persecution.

${ }_{63}$ Cf. Aur. Vict. Caes. 30, [Aur. Vict.] epit. 30, Eutr. 9.5, Jer. chron. a Abr. pp. 218-19 Helm, Oros. hist. 7.21.6, Zos. 1.26.2, Jord. Get. 104. There was also an outbreak under Gallienus. For complete testimonia see Hannan (n. 15), 13-18, supplemented by Clarke (n. 56), 3.154 n. 10.

${ }_{64}$ The death of Decius' son Hostilianus at this time is attributed to the plague by Aur. Vict. Caes. 30.2, [Aur. Vict.] epit. 30.2. Zosimus, on the other hand, holds that 
Hostilianus fell victim to Gallus' treachery (1.25.2); but the fact that his death could be held to have been due to the plague is itself good evidence that the plague had arrived by this time. For the date see C. Préaux, 'Trébonien Galle et Hostilianus', Aegyptus, 32 (1952), 152-7, at 155 n. 5 (not later than the end of October 251), J.F. Gilliam, 'Trebonianus Gallus and the Decii: III et I cos', in Studi in onore di Aristide Calderini e Roberto Paribeni (3 vols., Milan, 1956-7), 1.305-11 (not later than the middle of August). M.M. Sage, Cyprian (Patristic Monograph Series, 1; Philadelphia, 1975), 269 n. 1, following RE 8A.1988, maintains that the plague struck Rome in 250; but there are inadequate grounds for accepting this date, and the coins bearing the legend APOLL(INI) SALUTARI, which form the evidence cited by Sage in its support, were issued by Gallus, as the $R E$ article makes clear.

65 So e.g. E.W. Benson, Cyprian: His Life, his Times, his Work (London, 1897), p. xxii, Koch (n. 43), 140-8 ('Die Abfassungszeit der Schriften De mortalitate, Ad Demetrianum und De opere et eleemoynsis'), at 141 (with the opinions of other scholars given at 140), Hannan (n. 15), 3, G. Stramondo, Studi del 'De mortalitate' di Cipriano (Catania, 1964), 21-8 ('Data di composizione del "De mortalitate" '), at 28, Sage (n. 64), 381.

${ }_{66}$ This possibility is recognised by such as Monceaux (n. 39), 303, Saxer (n. 39), p. viii, and L. Duquenne, Chronologie des lettres de S. Cyprien: le dossier de la persécution de Dèce (Subsidia hagiographica, 54; Brussels, 1972), 160, all of whom, however, also recognise the possibility of 252. A. Harnack, Geschichte der altchristlichen Litteratur bis Eusebius. Teil 2: Die Chronologie. Band 2: Die Chronologie der Litteratur von Irenaeus bis Eusebius (Leipzig, 1904), 365, conservatively sets the work in the period 252-6.

${ }^{67}$ mort. 2, 15, 25.

${ }_{68}$ Dem. 3-5, 20, 23.

69 The arguments of Clarke (n. 56), 3.9-13, 213-14, 226, in favour of this dating (against 252) are persuasive; the likely month is May. For the notion of approaching persecution and prediction of the apocalypse see esp. epist. 57.1.2, 5.1-2; 58.1.2, 2.1-2, 7.1. The connection between mort. and epist. 57 and 58 is also made by Clarke, 3.215-16, 228, and by Stramondo (n. 65), 26-7, who, however, dates the letters (and thus mort.) to 252.

${ }^{70}$ The date is fixed by epist. 59.6.1, with which see Clarke (n. 56), 3.244 n. 27.

7 Cf. epist. 43.1.2. I accept the standard view that it is to these presbyters that Pontius refers at vita Cypr. 5.6.

72 Cypr. epist. 20.1.2 'nam sicut domini mandata instruunt, orto statim turbationis impetu primo, cum me clamore violento frequenter populus flagitasset, non tam meam salutem quam quietem fratrum publicam cogitans interim secessi, ne per inverecundam praesentiam nostram seditio quae coeperat plus provocaretur', Pont. vita Cypr. 7-8. Cyprian similarly defends his remaining in exile at epist. 7.1, 14.1.2. In fairness it should be said that Cyprian may genuinely have believed that the Church at Carthage would be better served by his withdrawal (as it may have been); but what is clear is that his flight was suspect. For a favourable representation of his action see C. Favez, 'La fuite de saint Cyprien lors de la persécution de Décius', REL 19 (1941), 191-201.

73 Cypr. epist. 8.

74 In epist. 43 Cyprian tells the Christian community at Carthage that he will be unable to return to them from exile before Easter $(43.1 .2,7.2)$; the next letter in chronological sequence, epist. 44, is written from Carthage around the middle of the year, following the disputed election of Cornelius as bishop of Rome (March 251) (see Clarke (n. 56), 2.223-4). 
75 Cf. epist. 43.4.1.

76 For the whole situation see esp. Cypr. epist. 15-17, with Sage (n. 64), 211-15. I agree with Sage, $213 \mathrm{n}$. 1, that the move to easy readmission of the lapsed may not have arisen solely from self-interest and hostility to Cyprian. But on the assumption that the group was essentially the same as that which later gathered around Felicissimus, and which Cyprian identifies with the presbyters who opposed his election as bishop (see epist. 43.1-3), personal animus must have played a significant part. The extent of the lapsing and the absence of Cyprian from the city afforded his opponents an opportunity they could never have anticipated.

77 Cf. Cypr. epist. 18.1.2, 19.2.1, 20.3.1-2.

78 Cf. Cypr. epist. 8.3.1, 30.8.

79 Felicissimus first appears in Cypr. epist. 41; soon after, Cyprian has linked him with his opponents in the presbyterate (epist. 43.1-3). For the date see Clarke (n. 56), 2.200, 211.

${ }^{80}$ Cf. Cypr. epist. 43.2.2, 3.2, laps. 15-16.

81 Cf. Cypr. epist. 41.2.1.

82 Cf. Cypr. epist. 42.

${ }^{83}$ For the condemnation of Felicissimus and the presbyters see Cypr. epist. 45.4.1 with Clarke (n. 56), 2.242 n. 30, epist. 59.9.1. For the identification of the five presbyters with those who opposed Cyprian's election to the episcopate see epist. 43.1-2. It is commonly held that it was at this council that Cyprian delivered laps. and unit.eccl., though there are reasons for thinking that this was not the case. It is also a vexed question whether unit.eccl. was addressed principally to the situation in Rome following Cornelius' election (for which see below) or to the threat of schism in Carthage; I incline to the latter view. For discussion, with further bibliography, see Clarke, 2.301-3, Sage (n. 64), 231-2 (with 232 n. 1), 241 n. 4, 245 n. 2 (whose arguments are not always sound).

${ }^{84}$ Cf. Cypr. epist. 55.17.3.

85 The strict position of the bishopless Roman church on the issue was communicated to Cyprian in Cypr. epist. 30, of which Novatianus was the author (cf. Cypr. epist. 55.5). Clarke (n. 56), 2.118, is right to point out that the views expressed in the letter, which is written in the name of the presbyters and deacons of Rome, cannot with certainty be regarded as the personal views of Novatianus; but in the light of his later position it would seem that his own opinions can, if anything, only have been toned down.

${ }_{86}$ See Sage (n. 64), 249-50. If the election did turn on the issue of the lapsed, it may be that Novatianus' own views had indeed been diluted in Cypr. epist. 30 (see above, n. 85), or else that they had hardened in the interim: for this suggestion see S.L. Greenslade, Schism in the Early Church (2nd edn., London, 1964), 40-1.

${ }^{87}$ For discussion of the whole episode see Sage (n. 64), 250-3.

${ }_{88}$ See Sage (n. 64), 253-5.

89 Cf. Cypr. epist. 46, 49.

90 Cf. Euseb. hist. eccl. 6.43 .2 (where Novatianus is mistakenly called Novatus).

$91 \quad$ Cf. Cypr. epist. 59.9.1.

92 For the events surrounding the consecration, and Cyprian's concern about the faction of Felicissimus and Fortunatus and the reliability of Cornelius as an ally, see Cypr. epist. 59, with Clarke (n. 56), 3.235-8.

${ }_{93}$ Cf. Cypr. epist. 59.9.2.

${ }_{94}$ See Clarke (n. 56), 3.213-14. A further point in favour of dating the amnesty to the 
Carthaginian council meeting of 253 rather than that of 252 is that the appointment of Fortunatus as bishop and Felicissimus' journey to Rome, which followed the 252 council (mentioned at Cypr. epist. 59.10.1), makes more sense in a context where the rug has not yet been pulled from under lapsist feet by the easing of penitential conditions.

95 See Cypr. epist. 66, with Clarke (n. 56), 3.321-2 (for the date), 327 n. 10. But it is impossible to be certain that Puppianus, whose attacks on him Cyprian seeks in this letter to rebut, was a member of the lapsist group. However that may be, there is a tendency in Cyprian scholarship to shorten the struggle which Cyprian had to wage with his opponents. Thus Sage (n. 64), 264, is quite wrong to say that after the 251 council 'the lapsists at home faded into obscurity since the bishop had undermined their position by conceding to their demands'; or that when Felicissimus travelled to Rome in 252 he was no longer a threat to Cyprian. The evidence points firmly the other way.

96 Cf. Pont. vita Cypr. 5.1, Cypr. epist. 43.1.2, 59.6.1. For the role of the laity in episcopal elections see Clarke (n. 56), 2.178 n. 1.

97 See above, p. 23, with nn. 68-9, for Dem. and epist. 58 (epist. 57 is concerned with approaching persecution but does not anticipate the imminent end of the world); also unit. eccl. 16 (AD 251), epist. 59.7.1, 13.4, 18.3 (252), Fort. pref. 1. The date of Fort. is uncertain, but it may well belong to 253 , and thus perhaps be contemporary with epist. 58 and mort.; in support of this see e.g. Koch (n. 43), 149-210 ('Die Abfassungszeit der Sprachsammlungen ad Fortunatum und ad Quirinum'), at 149-83, G. Alföldy, 'Der Heilige Cyprian and die Krise des römischen Reiches', Historia, 22 (1973), 479-501, at 486 n. 39, Clarke (n. 56), 3.227.

98 This is the commonly accepted dating; see e.g. Sage (n. 64), 382-3 (referring to the work as the Testimonia). Recently C. Bobertz, 'An Analysis of Vita Cypriani 3.6-10 and the Attribution of Ad Quirinum to Cyprian of Carthage', VChr 46 (1992), 112-28, has argued against Cyprian's authorship of the Ad Quirinum, suggesting (as others have done) that it should be ascribed to an earlier hand. The main difficulties which Bobertz identifies in the standard attribution of this work to Cyprian are genuine; but they are susceptible of other explanations. In any case, it is sufficient for my argument that Cyprian claimed the Ad Quirinum as his, a claim established by the prefaces to books 1-2 and book 3 of the work, the authenticity of which Bobertz does not dispute (unless there is a hint of some such doubt, in relation to the book 3 preface, at $124 \mathrm{n}$. 18, where Bobertz does not make his own views clear; the authenticity of the preface to books 1-2 is tacitly accepted at 125 n. 20).

99 The passage is cited also at Fort. 13, epist. 58.10.2, in both cases in a context concerning persecution.

100 Stuiber (n. 16), 465.

101 See above, pp. 13 and 20-21.

${ }_{102}$ Von Moos (n. 17), 2.7 (A 26), also reckons as consolatory Tert. castit. 1, and a letter from Pius, bishop of Rome (d. c. 154), to Iustus of Vienne (MGH, Epistolae, 3.87 (Epist. Vienn. 2)). But neither of these texts has anything to do with consolation (and the second is apparently spurious in any case).

103 See above, p. 13.

104 pp. $12-13$.

10s The idea of death as a release from the saeculum (mort. 15, 20) can be seen as a Christian development of the common (and not only consolatory) notion of death as a release from the miseries of human life generally (for instances see Scourfield (n. 34), 198-9); for 
death as an advance to a better state (mort. 22 'quis non ad meliora festinet?', where, however, the idea is not used in a directly consolatory way) cf. Sen. dial. 6.24.5; the use of words such as praemitti, praecedere, and proficisci (mort. 20) in expressing the notion of dying is readily paralleled in pagan literature, consolatory and non-consolatory (see Scourfield, 177); the essentially Christian topos that one should avoid grieving so as not to give unbelievers an opportunity to call Christian faith into question finds pagan parallels in cases where the consoland is urged not to grieve in case false conclusions are drawn from that grief (so Sulpicius ap. Cic. ad fam. 4.5.6, Sen. dial. 12.19.7). Other connections might be found, but none of great substance.

\section{University of the Witwatersrand, Johannesburg}

